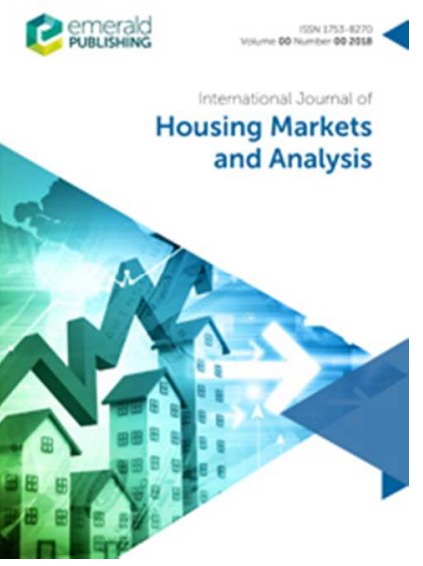

Household Mortgage Demand: A Study of the UK, Australia and Japan

\begin{tabular}{|r|l|}
\hline Journal: & International Journal of Housing Markets and Analysis \\
\hline Manuscript ID & IJHMA-03-2017-0029.R1 \\
\hline Manuscript Type: & Research Paper \\
\hline Keywords: & Mortgages, Panel data, Institutions, UK, Australia, Japan \\
\hline \multicolumn{2}{|l}{} \\
\hline
\end{tabular}

SCHOLARONE ${ }^{m}$

Manuscripts 


\title{
Household Mortgage Demand: A study of the UK, Australia and Japan
}

\begin{abstract}
Households combine their personal savings and mortgage debt to finance their home purchases. In developed countries, mortgage debt is the largest debt on a household's balance sheet and in these countries, the mortgage penetration rates are high. For the stability of the mortgage market and thereby the money market in an economy, it is important to understand households' mortgage demand decisions and riskiness of these borrowers. There are differences in mortgage systems among countries, which play an important role in determining the mortgage decisions that households make. These differences arise from the availability of types of mortgage instrument (adjustable versus fixed rate mortgages), length of fixed period for a fixed rate mortgage contracts, conditions of prepayment, tax treatment, lenders' constraints related to repayment, loan to value ratio, foreclosure and personal bankruptcy laws etc. These differences impact borrowers' choice of mortgage contract and mortgage demand.
\end{abstract}

This paper analyses the mortgage demand behaviour of households in the UK, Australia and Japan. Specific questions that have been asked relate to the factors that determine household mortgage demand, housing demand and loan to value ratio. Though the homeownership is a preferred tenure and the mortgages are 'recourse' loans, housing markets in these three countries operate in different mortgage market institutional structure. Results indicate that income elasticity of mortgage demand differ despite income elasticity of housing demand being similar. Mortgage institutions that pose constraints for borrowers also determine the extent of mortgage demand. Other factors such as demography, economic conditions have also played an important role in determining mortgage and housing demand.

\section{Introduction}

Benefits from homeownership cannot be understated in any society. Almost two-third of households in the UK, Australia and Japan live in ownership houses. The percentage homeownership rate has however declined recently from 70.6 percent in 2000 to 65.2 percent in 2012 in the UK from 69.5 percent in 2001 to 68.7 percent in 2012 in Australia. In Japan the homeownership rate has marginally increased from 61.1 percent in 2007 to 61.9 percent in 2013 (Source: https://tradingeconomics.com/japan/homeownership-rate). Mortgage has played a crucial role in enabling households to buy homes in 2012, nearly half of the homes were purchased using mortgage in the UK. However, this share of homes bought on mortgages has declined from 61.4 percent in 2000. In Australia, home purchasers with mortgage are more than 50 percent in 2011 and this has increased compared to 41 percent in 2001. These statistics indicate that though the homeownership rates in these countries are similar, the role that mortgages have played is somewhat varied.

The objective of this paper is to understand the causes for differences in household mortgage demand in the UK, Australia and Japan. This is important for the stability of overall economy as well, as the mortgage market plays a very important role in the transmission of monetary policy, which has a profound impact on the macro economy. The mortgage market and monetary market are intertwined and due to the linkages 
between the monetary market and the macro economy, changes in the mortgage market get transmitted to the macro economy. The proportion of fixed and variable rate mortgages is of great importance for the national economy as the interest rate shocks affect fixed and variable rate mortgages differently (Koblyakova, et al, 2014). The ARMs, which are linked to short term interest rate face far greater monetary policy risk than the FRMs. An economy, such as the UK, where the level of debt as a proportion of GDP is high and a large proportion of this debt is linked to adjustable rate mortgages, the risk of transmission of policy changes remain high. This, in times of crisis, poses challenges for effectiveness of monetary policy instruments to achieve financial stability.

In recent times, the Global Financial Crisis (GFC), is an example where the mortgage market caused the instability in the financial systems of various countries to various degrees. The financial and capital markets in the UK were strongly impacted due to the tight liquidity conditions that followed the GFC and this has affected the macro economy. Post GFC, the real GDP growth rate in the UK dropped to $-4.3 \%$ in 2009 and the economy did not regain its pre-crisis level of growth until 2014. The Australian financial and capital markets (monetary market) were not as badly influenced as the UK, and liquidity in the market was not so tight. One of the reasons could have been that Australia did not hold much of the asset-backed securities (mortgage backed securities and its derivatives) linked to the sub-prime crisis, which contained the impact of GFC in the country. The real GDP growth, though slowed, never became negative during the GFC. Similar to Australia, Japan also did not witness tight liquidity conditions post GFC. The real GDP growth rate in Japan has been low witnessing negative values frequently after the bubble burst in late 1990s during the so-called "lost decade(s)". The real GDP growth in Japan during the GFC was also negative with growth rates of $-3.7 \%$ and $-2.0 \%$ in 2008 and 2009, respectively. The strength of the linkage between the mortgage market and macro economy differs among countries depending on the characteristic of the mortgage market, its institutions and structure of mortgage debt. This paper investigates the demand side of the mortgage market.

Specifically, the paper aims to understand the drivers of mortgage market and their impact. To accomplish this objective, it is critical to analyse household behaviour over mortgage choice and its demand. In particular, what determines household mortgage demand? Furthermore what is the relation between mortgage demand and a particular mortgage instrument? Literature suggests that the mortgage demand by a household is derived from their housing demand or said alternatively, housing and mortgage demand are jointly determined (Leece, 2006; Koblyakova et al., 2014). Therefore, this paper analyses mortgage choice as simultaneously determined with mortgage demand and also with housing demand.

The three countries, the UK, Australia and Japan, included in this paper provide a context of very similar policy objective and consumer preferences with regards to homeownership but they offer diversity in mortgage market institutions and available instruments despite the fact that mortgages are recourse type of loans in these three countries. The institutions differ in terms of availability of mortgage contract types, implementation of foreclosure and personal bankruptcy laws. As has been observed earlier that the homeownership rates in three countries are similar, however, to achieve these very similar homeownership rates, the extent of mortgage debt that households have accessed and the type of mortgage instrument that they have chosen is different across these countries. Households in the UK and Australia have predominantly chosen 
adjustable rate mortgages, ARM (also called variable rate mortgages, VRM), while in Japan the choice has been quite varied from VRMs to short-term and to long-term housing loan instruments. The difference in the extent of mortgage penetration in these countries is reflected in the level of outstanding mortgage debt as a proportion of GDP. In the UK, the ratio of outstanding mortgage debt to GDP is 70\%, in Australia it is $80 \%$ and in Japan it is less than $30 \%$. Besides the type of mortgage instrument (ARM or fixed rate mortgages, FRM), length of fixed period of FRM, conditions imposed by lenders regarding prepayment, tax treatment, lenders' constraints (mortgage payment to income ratio, downpayment to house value ratio), foreclosure and bankruptcy laws and practices also differ among these three countries.

Despite the differences in practices employed in mortgage markets in the UK, Australia and Japan, a large proportion of households have fulfilled their homeownership dreams by accessing mortgage finance. Their decisions have involved the level of debt and the type of mortgage instrument (FRM or ARM).

With this background, this paper analyses the determinants of mortgage demand and housing demand of households in the UK, Australia and Japan. This is achieved by basing the analysis within the theoretical framework of mortgage demand (see Leece, 2004; Chapter 2). These models are highly suggestive of empirical specifications for econometric estimation of mortgage demand. The empirical estimation takes the form of econometric estimates of mortgage demand, housing demand and initial loan to value ratio as separate equations. Cross sectional estimations utilize data extracted from Understanding Society Survey (USS) for the UK, from The Household, Income and Labour Dynamics in Australia (HILDA) for Australia and from Keio Household Panel Survey (KHPS) for Japan.

The paper is structured as follows. Section 2 analyses the relevant literature while Section 3 details econometric methodology applied in the paper. Section 4 discusses the data. The penultimate section presents the findings and interpretation of the results and the final section forms the conclusion.

\section{Literature review}

Several factors influence the demand for mortgage debt within the mortgage market. Besides demand for housing (Follain, 1990; Jones, 1993), these incorporate efficiency of the mortgage system, lending conditions, availability of mortgage types, regulatory constraints and economic environment (Lea, 2011; Miles, 2012). In a perfectly efficient mortgage market, under the Modigliani and Miller's theoretical propositions, borrowers should be indifferent to the size, mortgage type and gearing features of the mortgage contract (Leece, 2004). However, the institutional features of a mortgage market imply varying degree of mortgage constraints, which affect mortgage debt and mortgage instrument choices (Diamond and Lea, 1992; Campbell and Cocco, 2003).

Factors that affect house price movements and changes in mortgage flows include changes in household demographic situations, personal disposable income and changes in interest and tax rates. Among empirical studies, Follain and Dunsky (1997) and Ling and McGill (1998) employed US household-level data in econometric estimates of 
mortgage demand. The results for household mortgage demand highlight the importance of demographic and economic factors such as age and personal income and highlight that tax savings, associated with interest deductions, significantly affect the size of mortgage debt. Leece $(2004,2006)$, using the UK data, suggests that borrowers' choices about mortgage debt and type of mortgage contract depend on opportunities to acquire the housing debt. Employing nominal interest rates and regional house price inflation as proxies for the user cost of owner occupation, their research recognizes the importance of differentials in regional house prices in the decisions on mortgage size. At the macroeconomic level, the stability of the mortgage finance system in a country also depends on the level of household indebtedness and the distribution of variable, or fixed rate contracts (Duca, et. al., 2010). The structural variations in housing finance systems impose various degrees of sensitivity to changes in policy rates, depending on household's leverage, size and type of mortgage debt (McLennan, et. al., 2000; Campbell, 2012). Papers that have also explored the within country regional variations in the mortgage markets, have suggested that the level of mortgage debt is the key factor for the differentials in the impact of monetary policy within the UK (Evans and McCormick, 1994; Leece 2004) and the US (Campbell, 2012). Results also suggest that liquidity constraints and higher mortgage interest burdens have effectively restricted the demand for mortgage debt.

Extending the discussion on mortgage demand to cross-country comparisons, the crosscountry variations in economic conditions, housing and mortgage market institutions adds another nuance to the discussion. Given that the tax regime and monetary policy structure differs in different countries impacting their house prices differently, it is expected that cross-country variations in house prices substantially influence the starting point of households in entering owner-occupation (Lea, 2010). House price variations also lead to variable expectations about capital gains, facilitating an increase/decrease in housing and mortgage demands depending on the direction of expectations and accordingly reinforcing house price positively/negatively (Taltavull de La Paz and White 2012). Thus, the differing economic conditions in various countries may result in different effect of monetary policy on mortgage market operation; however, academic research in this area has been hampered by paucity of cross country data availability (Bell and Lowe, 2000).

Among the few studies that explore mortgage choice decisions from the cross-national perspective, Badarinza, et. al., (2017) suggest that the mortgage markets are highly heterogeneous across countries, demonstrating varying effects over the space and time. Exploring whether households choose a mortgage contract responding to current interest rate regime or based on expected future changes in mortgage prices, Badarinza et al (2017) show that the structure of mortgage rates are strong predictors of mortgage choice decisions. Their findings suggest that in a tight lending markets, liquidity constrained households will choose the cheapest available options, with the aim to balance their current level of consumption and maximum level of the mortgage debt.

In their cross-country study, Dow and Montagoni (2007) consider the possibility of impact of differences in the cost for mortgage loans and availability of mortgage debt arising due to differences in mortgage policies on mortgage demand. Their research identifies differences in cross country variations in the housing finance costs. They also found that national financial institutions respond differently to changes in monetary 
policy reflecting cross-country variations in credit conditions. Thus, depending on the state of local industry and on the asset values of collateral, credit attributes may differ in different countries and regions. Further, considering the differences in the lending and borrowing channels, Dow and Montagoni (2007) provide empirical evidence of the cross-country differences of the various groupings of financial markets and intermediaries. Notably, cross country differences in the cost of credit is explained by the disproportional creation of critical mass of financial activity and intensity of mortgage intermediaries in certain countries.

Further, cross country difference in demographic trends and its influence on the housing market has been explored by Levin et al, (2009). Highlighting the importance of demographic factors on size of mortgage debt, findings suggest that differences in the rate of growth of age groups relevant to first time buyers are particularly important. They suggest that a decline in real house prices and mortgage borrowing levels are more likely to occur in the countries where younger population is expected to decline in size.

Cross country disparities in the distribution of income may also cause various responses from housing and mortgage markets across the countries. Besley et al, (2010) suggest that countries characterized by higher incomes and higher house prices provide better lending conditions for mortgage contracts.

Investigating cross country variations in mortgage debt decisions, Campbell (2012) examines the potential impact of national economic features on the mortgage market structure, which influences households' behavior towards debt. Household's demand for debt is governed by the choice of house location, the decision to become a homeowner and the choice of mortgage rate. The choice of mortgage rate relates to the risk of changes occurring in the macroeconomic environment that affects a household's circumstances. Results suggest that a mortgagee, who is constrained, faces significant risk from uncertainty and timing, as is implied by the variable mortgage rate option that she chooses. Given a cross countries' perspective, this may suggest that countries with the prevalent variable mortgage debt have inherently higher interest rate risks and are less financially stable.

Analyzing the role of differences in economic conditions at the regional level, Cho et al. (2012) suggest that mortgage risks differ due to differing underlying risks across regions which impart heterogeneity in mortgage loans. Analyzing the period 1993-2007 they indicate that a long term equilibrium relationships exist between the mortgage default rates and regionally differentiated economic and social variables associated with mortgage affordability and liquidity constraints such as incomes and unemployment rates, which impact a household's ability to afford mortgage repayments. It may be hypothesized that a similar outcome could be expected in at cross-country level because the economic and mortgage market condition would differ.

There is paucity of academic literature in understanding the impact of mortgage market institutions on mortgage debt. Mortgages in the UK, Australia and Japan are recourse loans implying that a lender may seek financial damages beyond the mortgages housing asset if the borrower fails to pay the liability, and if the value of the underlying asset is not enough to cover it. Theory would suggest that recourse should deter default on 
home loans and have implications for mortgage demand. However, the extent to which these recourses can be manifested differ across different countries and hence the effect on mortgage demand could differ. In the US, recourse/non-resource nature of housing loan is a state law generating different outcomes across states. In Australia, personal bankruptcies are low due to severe consequences of bankruptcy under Australian Law and difficulty that one faces in accessing finance after bankruptcy (Kitson et al., 2015). There is no specific protection afforded to bankrupts and if the "bankrupt is sole owner, and no other person has an interest (legal or equitable) in the property, neither the bankrupt nor the bankrupt's family has any right to remain in the possession of the home" (Mason and O'Mahony, 2014). If loan falls in arrears, the realization of the security property through sale can take between 8-12 months on average (Kitson et al. 2015). The process of foreclosure is also simple and requires an order from Registrar General on satisfying the conditions of default. In Japan, almost all mortgages are recourse with very tiny fraction being non-recourse (Asset Enhancement Securities Limited, 2005). The "Civil Execution Act: Minji Shikkoo Hoo: Code No. 4 - 1980, Article 22 " defines the court orders and processes required for foreclosure. However, the Japanese court procedure in mortgage foreclosure is slow and could take as much as 24 months (ibid). In the case of the UK, as discussed by Aron and Muellbauer (2016), the default rates during the Global Financial Crisis were low due to government's generous support for borrowers with payment problems and increased forbearance (by lowering the rate of repossessions and increasing the rate of arrears) by banks, lending to the view that foreclosure is not as ruthless as the definition of "recourse" would imply. Their estimates further highlighted that forbearance changed with economic conditions.

Summarizing the findings, previous research has used utility maximization theory from a life cycle perspective as a theoretical basis for analyzing mortgage demand, while recognizing mortgage market constraints related to liquidity and affordability. Previous studies inform the econometric specification and suggest several explanatory variables for inclusion in empirical model of mortgage demand. In an international context, it appears that the cross-country differences in interest rate regime, lending conditions, liquidity constraints, pricing of risks, demographic trends and macroeconomic fundamentals play a deterministic role in mortgage debt and mortgage choice decisions. However, the role of mortgage institutions in a cross-country analysis has been less investigated, which becomes a gap for further investigation. While present paper highlights the role of mortgage institutions, it leaves detailed investigation into the regulations and practices that impact mortgage demand for future research.

\section{The three-country context and the data}

Table 1 presents the key demographic, economic, housing and mortgage market characteristics in Australia, Japan and the UK. While the homeownership rates and household preference towards homeownership are similar in these countries, the socioeconomic and housing market environment is different. This makes these three countries interesting cases for understanding the drivers of mortgage demand.

Demographically too, the size of population is quite different between Australia, the UK 
and Japan. Population of Japan is the largest, while other two countries have almost half the population of Japan. Although the population of Japan is large, it is declining in absolute numbers, while the population in other two countries is growing owing to international immigration. These countries are facing an increase in the number of one-person household partly due to the delay in age of marriage (and due to nonmarriage) and partly due to population ageing. Rising life expectancy is further increasing the number of aged population. The life expectancy of Japan is the highest in the world and the rate of ageing is also the highest. Regarding fertility rate, there is a notable difference between three countries. Japan has been suffering from a low fertility for a long time, however Australia and the UK are not. The household size has become smaller in all three countries therefore the number of households is increasing in the UK and Australia but is decreasing in Japan because the total population decline.

Demographic differences impact housing market significantly. The number of houses exceeds that of households in Japan, then vacancy rate has been rising amounting to more than 13.5 percent (Moriizumi, 2015). On the other hand, there is a shortage of housing in the UK and Australia due to a strong pressure of demand for housing caused by increasing population. The vacancy rate in the UK has decreased from 17 percent in 2009 to 12 percent in 2014, while in Australia, it is about 10.7 percent in 2011(ibid). It is interesting that even though Australia faces population increasing, its vacancy rate keeps constantly low. Owing to shortage of housing in Australia and the UK, there is excess demand in these countries causing high volatility in house prices in these countries. On the other hand, housing prices, have been declining for a long time in Japan and volatility in house prices is not so large in Japan due to excess supply.

The homeownership rates in these three countries have been declining despite low mortgage rates, favourable tax treatment and several financial assistance by government, especially for first time buyers (Moriizumi, 2015). The homeownership rate among young households has been continuously declining, whereas the ownership rate for the elderly has been above the average rate of homeownership in these three countries. Moriizumi (2015), in case of Japan proposes that the reasons for declining homeownership among young households are factors such as late marriage or non- marriage, and economic and financial downturn. While declining fertility rate may increase expectations about bequest, delay in receiving bequest due to rising life expectancy is also causing delays in homeownership of young households (ibid). The fertility rate in Australia and the UK is not declining but the homeownership rate among young households in these countries is low. Late marriage or non-marriage leading to late formation of household is a common influence causing delays in homeownership across all countries.

Housing markets and mortgage markets operate within the broader economy. The impact of GFC on economy, financial markets and hence housing has been different among countries. The financial and capital markets in the UK were strongly impacted resulting in tightening of liquidity and slowdown in the economy. The real GDP growth rate of the UK dropped to $-4.3 \%$ in 2009. Australian financial and capital markets (monetary market) were not so badly affected as the UK, and liquidity was not so tight. One of the reasons probably was that Australia did not hold asset backed securities that were linked to sub-prime loans. The real GDP growth 
rate, though declined, never became negative during GFC. Similar to Australia, Japan was not strongly impacted by GFC with respect to liquidity tightness. The real GDP growth rate in Japan has been low having negative values often after the bubble burst in late 1991s, during the so called "lost decade(s)". The real GDP growth rate during GFC was also negative with $-3.7 \%$ and $-2.0 \%$ in 2008 and 2009, respectively. After GFC it recovered to the level of almost $2 \%$.

The unemployment rate rose with the GFC in all three countries but has dropped in the UK and Japan. The unemployment rate in Australia has not yet fallen to the pre-GFC levels and the labor market is yet to recover. The inflation rate is decreasing in all three countries and Japan has been suffering from deflation for a long period since 2000s. These differences in the macro economy are reflected in household economic conditions, which significantly influence household behavior towards borrowing and buying a house, especially the behaviour of young household and first time buyers.

Economic and financial factors, such as unemployment rate, house price, mortgage rates are closely related to each other. Rising house prices and house price volatility as in the UK and Australia certainly depresses the ownership rate, while low mortgage rates promote home purchases. Tight credit constraints, especially during and after the GFC has likely depressed home buying activity among young home buyers. As for Japan although house (land and real estate) prices and mortgage rates have been declining at the same time, homeownership rates has also fallen for decades. From the economic standpoint, income volatility and unemployment rate are related, which have been high in Japan due to the sluggish economic conditions that have prevailed since late 1991s. Besides the negative and positive impacts of demographics mentioned above, these economic and financial factors have significantly influenced the behavior of young home buyers in Japan.

The three countries included in this paper present quite different systems of mortgage structure. Australia and the UK are dominated by variable rate mortgages (VRM) with short-term initial fixed rate, while there is a wide range of interest rate structures in Japan, from VRM to FRM with short-term, medium-term (3-15years) and long-term (20-35 years) fixed rate mortgages. Convertible loan is also prevalent in Japan. Initial fixed-rate discounts are common in all three countries.

In a perfect market, as per Modigliani Miller hypothesis, these structures should not affect households' mortgage decisions. However, with asymmetric information and other inefficiencies, these differences may influence the behavior of mortgage borrower's mortgage choice.

As discussed in Moriizumi (2015), the spread between FRM and ARM has always been positive, as expected in the finance theory. In the UK during GFC, and in Australia in most years since 1990s, ARM and FRM rates were very close and the relationship had reversed very often even before the GFC. In Japan, Government Housing Loan Corporation (GHLC), before its abolition, directly provided a long-term mortgage to borrowers at low interest rates by policy. The rate on ARM did not often change and it was fixed to be higher than FRM (GHLC mortgage). Consequently, the share of FRM has been larger than that of ARM for a long time. However, after the abolition of GHLC 
the mortgage rate for ARM is lower than FRM and the spread between FRM and ARM has been within a very narrow range. Recently the share of ARM has been rising (Moriizumi, 2015).

Features of mortgage instruments across countries impact prospect borrowers in each country. The size of mortgage market and the share of ARM to FRM depends on which mortgage instrument borrowers select and to what extent they demand for. The share of ARM in the mortgage market is the largest in Australia. ARM's share is increasing in Japan amounting to more than $40 \%$.

Moriizumi (2015) notes that housing loan to income ratio during 2006-2010 is the highest in the UK, followed by Australia, and is the lowest in Japan. The ratio h a s d e creased in the UK and Japan after GFC, while in Australia it has stayed at high level. It is interesting issue therefore, whether or not households take out a loan to buy homes and to what proportion of house value do they finance using mortgage.

The paper uses three datasets. For Australia, The Household Income and Labour Dynamics in Australia (HILDA) panel survey data for years 2002 (wave 2), 2006 (wave 6) and 2010 (wave 10) have been employed. In HILDA dataset, these are the years where question on original mortgage amount was asked. For Japan, the Keio Housing Panel Survey (KHPS) data for years between 2004-2011 (all available waves) have been used. In case of KHPS, all existing waves of survey have asked the question regarding initial mortgage amount. Hence all the waves have been included in the research. For the UK, the paper uses the Understanding Society Survey (USS) for years 2009 and 2012. They are also years where original mortgage amount is available from the survey question.

The difference in the periods across three datasets does not pose problem as dummy for time in the estimation control for differences in period. This paper has taken advantage of the full data range that is available.

The descriptive statistics is presented in Table 1.

Table 1 indicates that in the Australian data, 7.4 percent of households have taken a fixed rate mortgage. The proportion of fixed rate mortgages in Japan is about 41.3 percent and for the UK is 39.4 percent, substantially higher than Australia. This clearly indicates the differences in preference and/or availability of different mortgage instruments. The average age of borrowers in Australian data is 42.3 years while in Japan the average age is 47.4 years and the UK is 39.4 years. This possibly indicates that households in the UK or Australia may be better positioned in terms of affordability and face less liquidity constraints than Japanese households. The mortgage payment to income ratio in Australia and Japan are very similar at around 23 and 22 percent respectively. In the UK, the mortgage payment to income ratio is about 17 percent.

\section{Econometric Methodology}

The modeling approach involves estimation of three equations using ordinary least squares: mortgage demand function, housing demand function and initial loan to value ratio function. Equations 1 to 3 represent formal structure of these equations. Equation 
1 models Mortgage demand as a function of independent variables - household income, household characteristics such as the age of borrower, household size, income and mortgage payment structure. Dummies for rural and urban locations, regions have also been included. In order to capture the differences in mortgage origination, dummies for mortgage originations have been included. The second equation models housing demand as a function of independent variables that relate to household characteristics and income. In order to capture the mortgage market characteristics, variables for mortgage instrument choice and payment to income ratio have also been included. The three equations to be estimated are as follows:

\section{1) Mortgage demand function:}

$$
\log \left(M_{i t}\right)=\alpha_{0}+\alpha_{1} X_{i t}+\alpha_{2} \log \left(Y_{i t}\right)+\varepsilon_{i t}
$$

\section{2) Housing demand function:}

$$
\log \left(V_{i t}\right)=\beta_{0}+\beta_{1} X_{i t}+\beta_{2} \log \left(Y_{i t}\right)+v_{i t}
$$

\section{3) Initial loan to value ratio function:}

$$
\log \left(M_{i t} / V_{i t}\right)=\Upsilon_{0}+\Upsilon_{1} X_{i t}+\Upsilon_{2} \log \left(Y_{i t}\right)+\eta_{i t}
$$

The description of variables is as follows:

Mortgage value at origination $\left(M_{i t}\right)$ : This is the amount of initial loan that households took out at the time of purchase of their house. Since mortgage amount is measured in local currency unit (i.e., AUD for Australia, Yen for Japan, and GBP for the UK), we take the natural logarithm of this variable. This allows us to interpret estimated coefficients as (semi-) elasticity (which does not depend on the unit of measurement).

Purchase price of house $\left(V_{i t}\right)$ : This is the price paid for house at the time of purchase.

Initial loan to value ratio $\left(M_{i t} / V_{i t}\right)$ : This reflects the loan as a percentage of value of house.

Mortgage instrument choice $\left(I_{i t}\right)$ : 1 if fixed interest rate mortgage, 0 otherwise. Fixed rate mortgages are defined as mortgages that remained fixed for at least three consecutive years since origination. In case of Japan, KHPS asks a direct question whether the mortgage is fixed rate. We simply use the answer to this question, which includes, in principle, any fixed rate mortgage. For Australia and the UK, HILDA and BHPS do not have survey questions that directly ask mortgage contract type. We therefore impute the type of contract by looking at respondent's repayment history. If the repayment for a mortgage is constant across three consecutive years, we assume that the mortgage is fixed rate contract. This approach of identifying fixed rate mortgage in the case of the UK is same as Koblyakova et al (2014).

Age Age is the age of household head in the sample at period ' $\mathrm{t}$ '. 
Household Size: Represents the size of household in period ' $\mathrm{t}$ '.

Number of children: Represents number of children in the household in period ' $t$ '.

Gross household income $\left(Y_{i t}\right)$ : Annual gross income of household in local currency in period ' $\mathrm{t}$ '.

Payment to income ratio: This variable represents mortgage payment to income ratio in period ' $t$ '.

Urban-rural dummies: 1 if the property is located in urban areas; 0 otherwise.

Regional dummies: These are dummies for different regions in a country.

Dummies for mortgage origination years: These are dummies for years of origination of mortgage.

The purpose of equation (3) above is to explore an important relation between mortgage demand and housing demand. By definition, income elasticity for initial LTV is the difference between income elasticity for purchase price of home and mortgage amount. Taking the difference between equations (1) and (2) yields:

$\log \left(M_{i t}\right)-\log \left(V_{i t}\right)=\log \left(M_{i t} / V_{i t}\right)=\Upsilon_{0}+\Upsilon_{1} X_{i t}+\Upsilon_{2} \log \left(Y_{i t}\right)+\eta_{i t}$,

which implies that $\mathbf{\Upsilon}_{0} \equiv \boldsymbol{\alpha}_{0}-\boldsymbol{\beta}_{0} ; \boldsymbol{\Upsilon}_{1} \equiv \boldsymbol{\alpha}_{1}-\boldsymbol{\beta}_{1} ; \boldsymbol{\Upsilon}_{2} \equiv \boldsymbol{\alpha}_{2}-\boldsymbol{\beta}_{2}$.

Estimation of equation 3 allows us to capture the difference in coefficients of independent variables in mortgage demand and purchase price of house equations. This is particularly important for the variable, "gross household income". The coefficient of gross household income in mortgage demand function is the income elasticity of mortgage and the coefficient of gross household income in housing demand function is the income elasticity of purchase price of house. The difference between the two elasticity estimates (as measured by the coefficient of income in initial loan to value function) allows us to understand the role of the mortgage market institution in determining deviation in demand for mortgages in response to changes in income from demand for housing in response to changes in income. We utilize this feature to understand how these deviations move over time.

The paper estimates the three functions described above for the UK, Australia and Japan. In order to ascertain the equality of coefficients of various variables across these countries, a test for coefficient equality has been conducted (Chow, 1960).

\section{Results}

The estimates of the three functions are presented in Tables 2, 3 and 4 . The choice of fixed rate mortgages negatively influenced the demand for mortgage in all three countries. The fixed rate mortgages lead to smaller size debt for liquidity-constrained households. The price effect and large positive premium associated with fixed rate mortgages lead to lower mortgage debt. The coefficient is much higher for Australia 
than for the UK and Japan. This may be due to the prevalence for variable rate mortgages to a greater extent in Australia and a likely selling of these mortgage contracts to households by financial advisers. The spread that lenders have charged for FRM over ARM is low in Australia compared to the UK. The low interest environment has continued in Australia even after GFC.

Looking at the life cycle factors, the coefficient of Age has a positive sign for the UK while negative for Australia and Japan. In the UK, households tend to acquire larger properties in later stage of life (Koblyakova et al., 2014) and that explain the positive sign. This is confirmed by the housing demand function (presented in Table 3). The effect of age on size of property, however, is at decreasing marginal rate as indicated by small size coefficient of squared term of age variable. In case of Australia, however, while households buy larger properties as they age (as seen from positive sign of coefficient for Age in housing demand function, Table 3), the tendency to take out larger mortgage debt with age declines. It's likely that the risk of taking out larger loans due to the recourse nature of debt in Australia deters households from increasing their debt. While the mortgages are recourse loans in the UK and Japan as well, Australian foreclosure and bankruptcy laws operate quite expediently in case of a mortgage default compared to other two countries. Households increase their proportion of equity contribution as they buy larger houses. In Japan, the size of debt declined with age and so did housing demand. The sign of the coefficient of household size in mortgage demand function is negative for Australia and Japan while positive for the UK. In case of Australia, it could be possible that larger household size is crowding out demand for mortgage debt (Table 2) and housing (Table 3), but reliability on this explanation is weak as the coefficients are insignificant. The reliability on the sign of coefficients of household size in the UK and Japan is also weak due to insignificance of the estimates.

With higher number of children, households in the UK, Australia and Japan desire bigger homes and they take out bigger debts in order to fulfill their requirements. The positive coefficient of mortgage payment to income ratio reflects the borrowing constraints and lending market conditions. What is interesting is the relatively high payment to income ratio elasticity for mortgage demand in the UK than in Australia or Japan. This reflects that relatively the UK mortgage market is less constrained than Australia and Japan. The payment to income elasticity for housing demand (Table 3 ) is very similar across three countries. This is important as it indicates that households do not increase their housing demand due to increase in payment to income ratio but rather increase their component of debt to finance the purchase in the UK. Given that the policies of government and lenders' attitude towards households who face income stress is accommodative and supportive in the UK (Aron and Muellbauer, 2017), despite mortgages being recourse, explains household behaviour. In Japan and Australia, the recourse nature of mortgages poses restrictive conditions for households.

The most important result of the analysis is the difference in income elasticity for mortgage demand among three countries with the UK being the highest (Table 2). The income elasticity of housing demand (Table 3) is also higher for the UK than Australia and Japan but the difference is not as big as in the case of income elasticity of mortgage demand. One possible argument for small income elasticity of mortgage demand for Japan could be due to the narrower range of housing options or greater willingness of households to pay for other consumption/investment items. In order to see if these 
alternative explanations are indeed true, we look at the estimation results for (log of) purchase price of housing and the initial loan-to-value ratio functions. If mortgage demand in Japan is income inelastic due to smaller housing options or greater demand for other consumption/investment items, then income elasticity for purchase price of housing would also be small as well. The results (Table 3) shows that income elasticity for purchase price of housing in Japan are similar (though statistically different in some cases) to the UK and Australia. This suggests that relatively small income elasticity for mortgage demand in Japan is a result of different lending practice (i.e., mortgage lenders in Japan tend to respond less to the rise in household income levels) and lenders' forbearance during defaults. The results are similar for Australia and Japan.

Regression results for initial LTVs are shown in Table 4. While estimated income elasticity of LTV is comparable between Australia and UK, it is strikingly different for Japan. The negative coefficient for Japan can be a result of different income responses to housing demand and mortgage lending. If richer households tend to purchase more expensive homes, whereas mortgage amount does not rise sufficiently, income elasticity for initial LTV can be negative (i.e., richer households tend to have lower LTVs). To examine this further, we separate the sample based on the purchase year of housing (prior to 1990, 1991-1995, 1996-2000, 2001-2005 and after 2006), and estimate the same regression models for LTVs. The results are shown in Table 5, which shows that the negative coefficient of household income is observed only for mortgages originated between 1991 and 2000, which may be due to reluctance on the part of mortgage lenders to extend new loans. Again this is the reflection of the mortgage market conditions, which are far easier in the UK. Aron and Muellbauer (2016) argued that in the UK, generous government policies lowered the foreclosure by 21 per cent and lenders' forbearance reduced foreclosure by an additional 13 per cent. In the UK, lenders can access other assets and other incomes of borrowers for up to seven years to settle the debt. In practice, the foreclosure happens after all other supportive policies of government and lenders fail to cure the situation, which is not frequent occurrence. In Japan in case of default the underlying lien (mortgage) is transferred from a bank to a credit guarantee company who then subrogates the debt, usually by auction. If after the auction, the company cannot recover the debt, it accesses other assets of the borrower, as the loan is recourse loan. Sometimes short sale of underlying property is also a way that is used to recover unpaid debt. When the default is caused by a borrower's death, the outstanding debt is completely covered by private insurance company. A borrower is required by the bank to take out the life insurance. On the other hand if default is caused by illness of a borrower and the borrower does not have insurance that covers illness, the property is foreclosed. For a brief period of December 4, 2009 until March 31, 2013 "Moratorium law" was enacted which allowed borrowers to ask lenders to change (relax) the terms of contract; amount of payment or amortization term when borrowers were facing payment stress and lenders were required to approve such requests as far as possible. However, this law has expired now. During extreme natural and economic events such as "bubble" burst in Japan, the government implicitly supported non-bank financial institutions to prevent bankruptcies due to rising defaults and allowed borrowers to negotiate their payments to reduce the burden. Generally speaking the recourse loan is restrictive for a borrower in Japan except in cases of extreme events. Australia mortgage market is restrictive in events of default. The loans are foreclosed and disposed off in the event of default in fairly short period without much opportunity for borrower to renegotiate. Being recourse loan, lenders also have 
claim to other assets of borrowers to cover their loans.

The discussion above indicates that the mortgage market regulatory framework and institutional culture plays an important role in determining mortgage demand. This is an important area for future research.

\section{Conclusion}

This paper analyses the mortgage demand and housing demand in the UK, Australia and Japan. There are large differences in mortgage systems among these three countries, for instance, type of mortgage instrument (ARM vs FRM), length of fixed period of FRM, conditions of prepayment, tax treatment, lenders' constraints (mortgage payment to income ratio, downpayment to house value ratio) etc., which impact borrowers' choice of mortgage and its demand. The comparative analysis, however, brings out interesting results related to mortgage and housing demand, the most important being the mortgage institutional structure particularly related to foreclosure. For the markets where the mortgages are recourse loans, borrowers may borrow less compared to markets that have non-recourse loans because in the case of default, recourse loans allow lenders to foreclose any asset in addition to the mortgaged property to recover outstanding loans. This is particularly true during declining house price conditions. While the mortgage in the UK is a recourse loan like Australia and Japan, lenders foreclose properties only in extreme situations where government support or lenders renegotiations don't alleviate borrowers payment stress. This is not the case in Japan and Australia. This has resulted in higher income elasticity of mortgage demand in the UK than the other two markets.

An interesting finding from the study is that though there are large differences in the mortgage system (market) among three countries, borrowers when they choose a FRM their mortgage amounts are less than otherwise. Further to the conclusions of Naoi, Moriizumi and Yukutake (2013) and Kobliyakova et al (2014) where they show that a risky borrower chooses ARM as mortgage instrument, this paper shows that, in addition, a FRM borrower borrows less than an ARM borrower. This reinforces further that FRM borrowers are less risky than ARM borrowers. The FRM borrower is not a short-sighted decision maker and makes its plan including repayment of loan on a long term basis despite of length of the fixed term that is available in the market. Therefore the choice of mortgage instrument is a good screening device for distinguishing between a safe borrower and a risky borrower.

Housing market conditions have also played an important role in determining mortgage demand. During the period of analysis in this paper, while Australia experienced secular rise in house prices, Japan suffered from constant decline. The UK also witnessed upward trend in house prices from 1990 onwards except after the GFC when the prices fell. If we look at the function with initial LTV as a dependent variable, the income coefficient for Japan turned out to be negative for mortgages originated between 1991 and 1995, the period in which Japan's house price dropped significantly after the bubble burst, the so called "lost decade(s)".

As is often said that the Japanese are in general risk-averse, households don't like to borrow much, even though they are in the highest income class. High income 
households save more for the down payment, which implies that the mortgage penetration at the economy level is very low. In fact from the micro data it is evident that a household does not borrow much, which implies low income elasticity of mortgage demand. In other words, attitudes toward risk are different among the three countries and this is reflected in the income elasticity of mortgage demand. Risk also arises from the way foreclosure laws are implemented. In Japan and Australia, the laws are implemented expediently in comparison to the UK. This leads to lower elasticity of mortgage demand in Australia and Japan than the UK. The income elasticity for the UK is the largest among the three countries. This implies that the impact of change in mortgage market such as the rise and fall of mortgage rate, increase in number of default, arrears or delinquency etc., on monetary market in the UK is the strongest in the three countries. This is consistent with the fact that during the GFC the UK was affected most significantly among the three countries.

Demographic factors also explain the differences in mortgage demand between three countries. The population is growing in the UK and in Australia, while it is declining in Japan. Japan has been suffering from fertility decline for a long period. Even though fertility is declining in Australia and the UK, population is increasing owing to migration. These demographic factors impact income elasticity of housing demand because households demand less house space due to the decline in the number of children. Declining fertility can prompt inter-vivos transfer or increase its amount, while it reduces the mortgage demand.

Increasing population in Australia and the UK has a strong pressure for housing demand, causing mortgage demand to rise. On the contrary there is an excess supply in housing market in Japan, which may imply that the mortgage market in Japan may not be as active as in Australia and the UK. Further investigation indicates that as age of household advances a household borrows more until certain age in Australia and the UK, however, the impact of age on mortgage borrowing is opposite in Japan. Households borrow more during young age in Australia and the UK. In Japan, however, due to excess supply in the housing market, low fertility and high ageing rates, borrowers borrow less. This suggests that the linkage between mortgage and monetary markets will be weak in the future in Japan, while those of Australia and the UK will be stronger for a long time

\section{References}

ALM J. and FOLLAIN J. (1987) "Consumer demand for adjustable rate mortgages", Housing Finance Review 6, 11-17.

ARON J. and MAUELLBAUER J. (2017) "Modelling and forecasting mortgage delinquency and foreclosure in the UK", Journal of Urban Economics, Vol. 94, pp. 32-53.

BELL M. and LOWE R. (2000) "Building Regulation and Sustainable Housing. Part 1. A Critique of Part L of the Building Regulations 1995 for England and Wales", Structural Survey, 18-1. 
BESLEY, T., MEADS, N. and SURICO, P. (2010) "Risk Heterogeneity and Credit Supply: Evidence from the Mortgage Market”, Bank of England Discussion Paper 29.

BRUECKNER J. (1986) "The pricing of interest rate caps and consumer choice in the market for adjustable-rate mortgages", Housing Finance Review 5, 119-136.

BRUECKNER J. (1994) “The demand for mortgage debt: some basic results”, Journal of Housing Economics 3, 1-21.

BRUECKNER J. and FOLLAIN J. (1988) "The rise and fall of the ARM: an econometric analysis of mortgage choice", Review of Economics and Statistics 10, 93-102.

CAMPBELL J. and COCCO J. (2003) "Household risk management and optimal mortgage choice", Quarterly Journal of Economics November, 1449-1494.

CAMPBELL J. and COCCO J. (2007) "How do house prices affect consumption? Evidence from micro data", Journal of Monetary Economics 54, 591-621.

CAMPBELL, J. (2012) “Mortgage Market Design”, Review of Finance 17 (1), 1-33.

CHO, Y., HWANG, S., and SATCHELL, S. (2012) "The optimal mortgage loan portfolio in UK regional residential real estate", The Journal of Real Estate Finance and Economics, 45 (3), 645-77.

Chow G. (1960) "Test of Equality Between Sets of Coefficients in Two Linear Regressions", Econometrica, 28-3.

DOW, S. and MONTAGONI, A. (2007) "The regional transmission of UK monetary policy", Regional Studies, 41-6.

EVANS P. and MCCORMICK B. (1994) "The new pattern of regional unemployment: causes and policy significance", Economic Journal 104, 633-647.

FOLLAIN J. (1990) “Mortgage choice”, AREUEA Journal 18(2), 125-144.

FOLLAIN J. and DUNSKY R. (1997) "The demand for mortgage debt and the income tax", Journal of Housing Research 8(2), 155-200.

JONES L. (1993) “The demand for home mortgage debt”, Journal of Urban Economics 33, $10-28$.

KOBLYAKOVA, A. HUTCHISON, N. and TIWARI, P. (2014) "Regional Differences in Mortgage Demand and Mortgage Instrument Choice in the UK", Regional Studies, 48-9, 1499-1513. 
LING D. and MCGILL G. (1998) "Evidence on the demand for mortgage debt by owneroccupiers", Journal of Urban Economics 44, 391-414.

LEA, M. (2010) "Sources of funds for mortgage finance. Journal of Housing Research", 1 (1), 87-98.

LEECE D. (2000) "Household choice between fixed and floating rate debt: A binomial probit model with correction for classification Error", Oxford Bulletin of Economics and Statistics 62, 61-82.

LEECE D. (2001) "Regressive interest rates expectations and mortgage instrument choice in the United Kingdom housing market", Real Estate Economics 29, 589-614.

LEECE D. (2004) "Economics of the Mortgage Market: Perspectives on Household Decision Making”, Blackwell, London.

LEECE D. (2006) “Testing a theoretical model of mortgage demand on UK data”, Applied Economics 38, 2037-2051.

LEVIN E., MONTAGNOLI A. and WRIGHT R. (2009) "Demographic change and the housing market: evidence from a comparison of Scotland and England", Urban Studies 46(1), 27-43.

MEADOR, M. (1992) "The effect of mortgage laws on home mortgage rates", Journal of Economics and Business, 34 (2), 143-48.

MILES D. (2003) “The UK Mortgage Market: Taking a Longer-Term View - Interim Report", HM Treasury, London.

MILES D. (2004) “The UK Mortgage Market: Taking a Longer-Term View - Final Report”, HM Treasury, London.

MORIIZUMI, Y. (2015) "International Comparison of Housing and Mortgage Markets: Australia, Japan and the United Kingdom”, mimeo.

NAOI M., MORIIZUMI Y. and YUKUTAKE N. (2013) "Income Risk and Mortgage Choice among Japanese Households," February. (Available at SSRN)

OSTAS J. (1977) "Regional differences in mortgage financing costs: a re-examination", Journal of Finance 32(5), 1774-1778.

SCHAAF A. H. (1966) "Regional differences in mortgage financing costs", Journal of Finance 21, 85-94.

TALTAVULL de LA PAZ, P. and WHITE, M. (2012) "Fundamental drivers of house price change: the role of money, mortgages, and migration in Spain and the United Kingdom", Journal of Property Research, 29(4), 341-367. 
TSATSARONIS, K. and ZHU, H. (2004)"What drives housing price dynamics: crosscountry evidence", BIS Quarterly Review, 65-78.

VICKERY, J. (2006) "Interest Rates and Consumer Choice in the Residential Mortgage Market", Federal Reserve Bank of New York Working Paper.

BADARINZA, C., CAMPBELL, J. and RAMADORAI, T. (2017) What Calls to ARMs? International Evidence on Interest Rates and the Choice of Adjustable Rate Mortgages. Management Science.

DUNGEY, M., TCHATOKA, F. , WELLS, G. and YANOTTI, M. (2015) Mortgage Choice determinants: The Role of Risk and Bank Regulation, Economic Record, 91-295, pp. 417437.

DUCA, J., MUELLBAUER, J. and MURPHY, A. (2010) Housing Markets and the Financial Crisis of 2007-2009: Lessons for the Future. Journal of Financial Stability, 6(4), 203-217.

CAMPBELL, J. (2012) Mortgage Market Design. Review of Finance 17 (1), 1-33. 
Tables

10

11

12

13

14

15

16

17

18

19

20

21

22

24

25

26

27

28

29

30

31

32

33

34

35

36

37

38

39

40

41

42

43

44

45

46

47

48

49

50

51

52

53

54

55

56

57

58

59

60 
Table 1: Descriptive Statistics

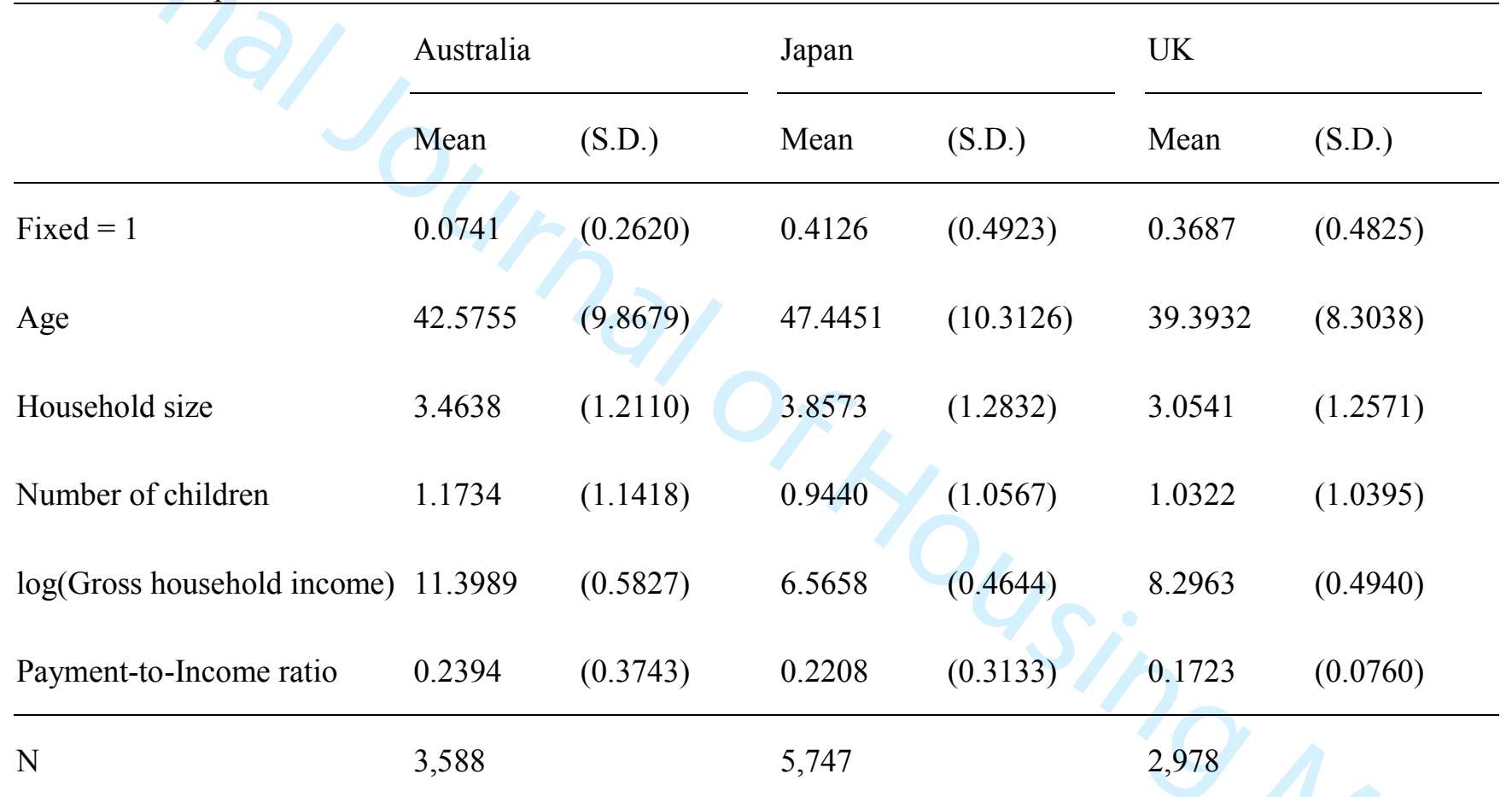

Note: Gross household income is measured in each country's currency unit. However, in the estimation, this doesn't cause any problems since we take a log for both dependent and independent (income) variables, allowing us to interpret estimated coefficients as income elasticity (which are unit-free). 


1
2
3
4
5
6
7
8
9
10
11
12
13
14
15
16
17
18
19
20
21
22
23
24
25
26
27
28
29
30
31
32
33
34
35
36
37
38
39
40
41
42
43
44
45
46
47
48
59
50
50
51
53
55


Table 2: Mortgage demand function

\begin{tabular}{|c|c|c|c|c|c|c|c|c|c|c|c|}
\hline \multirow{3}{*}{$\begin{array}{l}\text { Dependent var.: } \\
\text { log(mortgage amount })\end{array}$} & \multicolumn{5}{|c|}{ Regression results } & \multicolumn{6}{|c|}{ Test for coefficient equality } \\
\hline & Australia & & Japan & UK & & All & & $\begin{array}{l}\text { AUS } \\
\text { JPN }\end{array}$ & vs & $\begin{array}{ll}\text { AUS } & \text { vs } \\
\text { UK }\end{array}$ & s \\
\hline & $\begin{array}{l}\text { Coef. } \\
\text { (S.E.) }\end{array}$ & & $\begin{array}{l}\text { Coef. } \\
\text { (S.E.) }\end{array}$ & $\begin{array}{l}\text { Coef. } \\
\text { (S.E.) }\end{array}$ & & $\begin{array}{l}\text { F value } \\
\text { (p-value) }\end{array}$ & & $\begin{array}{l}\text { F value } \\
\text { (p-value) }\end{array}$ & & $\begin{array}{l}\text { F value } \\
\text { (p-value) }\end{array}$ & \\
\hline Fixed rate mortgage $=1$ & $\begin{array}{l}-0.0630 \\
(0.0250)\end{array}$ & & $\begin{array}{l}-0.0294 \\
(0.0128)\end{array}$ & $\begin{array}{l}-0.0184 \\
(0.0083)\end{array}$ & & $\begin{array}{l}1.5331 \\
(0.2159)\end{array}$ & & $\begin{array}{l}1.4287 \\
(0.2320)\end{array}$ & & $\begin{array}{l}2.8726 \\
(0.0901)\end{array}$ & \\
\hline Age & $\begin{array}{l}-0.0038 \\
(0.0056)\end{array}$ & & $\begin{array}{l}-0.0108^{* *} \\
(0.0048)\end{array}$ & $\begin{array}{l}0.0109 \\
(0.0046)\end{array}$ & & $\begin{array}{l}5.4948 \\
(0.0041)\end{array}$ & *** & $\begin{array}{l}0.9026 \\
(0.3421)\end{array}$ & & $\begin{array}{l}4.1055 \\
(0.0428)\end{array}$ & ** \\
\hline$(\mathrm{Age} / 100)^{2}$ & $\begin{array}{l}0.0029 \\
(0.0065)\end{array}$ & & $\begin{array}{l}0.0131 \\
(0.0050)\end{array}$ & $\begin{array}{l}-0.0216 \\
(0.0058)\end{array}$ & *** & $\begin{array}{l}10.5210 \\
(0.0000)\end{array}$ & *** & $\begin{array}{l}1.5640 \\
(0.2111)\end{array}$ & & $\begin{array}{l}7.9908 \\
(0.0047)\end{array}$ & $* * *$ \\
\hline Household size & $\begin{array}{l}-0.0155 \\
(0.0125)\end{array}$ & & $\begin{array}{l}-0.0062 \\
(0.0062)\end{array}$ & $\begin{array}{l}0.0044 \\
(0.0074)\end{array}$ & & $\begin{array}{l}1.1209 \\
(0.3260)\end{array}$ & & $\begin{array}{l}0.4419 \\
(0.5062)\end{array}$ & & $\begin{array}{l}1.8692 \\
(0.1716)\end{array}$ & \\
\hline Number of children & $\begin{array}{l}0.0321 \\
(0.0129)\end{array}$ & & $\begin{array}{l}0.03133^{* * *} \\
(0.0080)\end{array}$ & $\begin{array}{l}0.0140 \\
(0.0086)\end{array}$ & & $\begin{array}{l}1.2807 \\
(0.2779)\end{array}$ & & $\begin{array}{l}0.0025 \\
(0.9598)\end{array}$ & & $\begin{array}{l}1.3600 \\
(0.2436)\end{array}$ & \\
\hline $\begin{array}{l}\log \text { (gross household } \\
\text { income) }\end{array}$ & $\begin{array}{l}0.5274 \\
(0.0208)\end{array}$ & & $\begin{array}{l}0.3356^{* * *} \\
(0.0191)\end{array}$ & $\begin{array}{l}0.8888 \\
(0.0119)\end{array}$ & *** & $\begin{array}{l}340.6352 \\
(0.0000)\end{array}$ & ${ }^{* * *}$ & $\begin{array}{l}46.2451 \\
(0.0000)\end{array}$ & *** & $\begin{array}{l}227.6039 \\
(0.0000)\end{array}$ & $* * *$ \\
\hline $\begin{array}{l}\log \text { (payment-to-income } \\
\text { ratio) }\end{array}$ & $\begin{array}{l}0.3576 \\
(0.0286)\end{array}$ & *** & $\begin{array}{l}0.28077^{* * *} \\
(0.0141)\end{array}$ & $\begin{array}{l}0.8208 \\
(0.0134)\end{array}$ & *** & $\begin{array}{l}409.9167 \\
(0.0000)\end{array}$ & & $\begin{array}{l}5.8268 \\
(0.0158)\end{array}$ & $* *$ & $\begin{array}{l}215.3948 \\
(0.0000)\end{array}$ & $* * *$ \\
\hline $\begin{array}{l}\text { Adjusted } \mathrm{R}^{2} \\
\mathrm{~N}\end{array}$ & $\begin{array}{l}0.6832 \\
3,588\end{array}$ & & $\begin{array}{l}0.2825 \\
5,747\end{array}$ & $\begin{array}{l}0.8169 \\
2,978\end{array}$ & & & & & & & \\
\hline
\end{tabular}


Table 3: Housing demand function

\begin{tabular}{|c|c|c|c|c|c|c|c|c|c|c|c|c|}
\hline \multirow{3}{*}{$\begin{array}{l}\text { Dependent var.: } \\
\log (\text { purchase price of } \\
\text { home) }\end{array}$} & \multicolumn{6}{|c|}{ Regression results } & \multicolumn{6}{|c|}{ Test for coefficient equality } \\
\hline & Australia & & Japan & & UK & & All & & $\begin{array}{l}\text { AUS } \\
\text { JPN }\end{array}$ & & $\begin{array}{l}\text { AUS } \\
\text { UK }\end{array}$ & VS \\
\hline & $\begin{array}{l}\text { Coef. } \\
\text { (S.E.) }\end{array}$ & & $\begin{array}{l}\text { Coef. } \\
\text { (S.E.) }\end{array}$ & & $\begin{array}{l}\text { Coef. } \\
\text { (S.E.) }\end{array}$ & & $\begin{array}{l}\text { F value } \\
\text { (p-value) }\end{array}$ & & $\begin{array}{l}\text { F value } \\
\text { (p-value) }\end{array}$ & & $\begin{array}{l}\text { F value } \\
\text { (p-value) }\end{array}$ & \\
\hline Age & $\begin{array}{l}0.0224 \\
(0.0058)\end{array}$ & ${ }^{* * *}$ & $\begin{array}{l}-0.0201 \\
(0.0034)\end{array}$ & *** & $\begin{array}{l}0.0172 \\
(0.0060)\end{array}$ & & $\begin{array}{l}27.4778 \\
(0.0000)\end{array}$ & & $\begin{array}{l}39.5351 \\
(0.0000)\end{array}$ & & $\begin{array}{l}0.3718 \\
(0.5420)\end{array}$ & \\
\hline$(\text { Age } / 100)^{2}$ & $\begin{array}{l}-0.0135 \\
(0.0066)\end{array}$ & ** & $\begin{array}{l}0.0267 \\
(0.0035)\end{array}$ & & $\begin{array}{c}-0.0075 \\
(0.0069)\end{array}$ & & $\begin{array}{l}19.9880 \\
(0.0000)\end{array}$ & *** & $\begin{array}{l}28.8777 \\
(0.0000)\end{array}$ & *** & $\begin{array}{l}0.3972 \\
(0.5285)\end{array}$ & \\
\hline Household size & $\begin{array}{l}-0.0087 \\
(0.0121)\end{array}$ & & $\begin{array}{l}0.0139 \\
(0.0051)\end{array}$ & ${ }^{* * *}$ & $\begin{array}{l}-0.0168 \\
(0.0106)\end{array}$ & & $\begin{array}{l}4.2578 \\
(0.0142)\end{array}$ & ** & $\begin{array}{l}2.9599 \\
(0.0854)\end{array}$ & * & $\begin{array}{l}0.2528 \\
(0.6151)\end{array}$ & \\
\hline Number of children & $\begin{array}{l}0.0447 \\
(0.0128)\end{array}$ & ${ }^{* * *}$ & $\begin{array}{l}0.0027 \\
(0.0063)\end{array}$ & & $\begin{array}{l}0.0525 \\
(0.0119)\end{array}$ & ${ }^{* * *}$ & $\begin{array}{l}9.3407 \\
(0.0001)\end{array}$ & *** & $\begin{array}{l}8.7550 \\
(0.0031)\end{array}$ & *** & $\begin{array}{l}0.1978 \\
(0.6565)\end{array}$ & \\
\hline $\begin{array}{l}\log \text { (gross household } \\
\text { income) }\end{array}$ & 0.4059 & $* * *$ & 0.3742 & ${ }^{* * *}$ & 0.4956 & ${ }^{* * *}$ & 15.6439 & & 1.7821 & & 13.5332 & *** \\
\hline & $(0.0183)$ & & $(0.0152)$ & & $(0.0162)$ & & $(0.0000)$ & & $(0.1819)$ & & $(0.0002)$ & \\
\hline $\begin{array}{l}\log \text { (payment-to-income } \\
\text { ratio) }\end{array}$ & 0.1744 & $* * *$ & 0.1929 & ${ }^{* * *}$ & 0.2055 & $* * *$ & 0.7989 & & 0.8641 & & 1.4989 & \\
\hline & $(0.0166)$ & & $(0.0110)$ & & $(0.0192)$ & & $(0.4499)$ & & $(0.3526)$ & & $(0.2209)$ & \\
\hline Adjusted $\mathrm{R}^{2}$ & 0.6683 & & 0.3285 & & 0.6763 & & & & & & & \\
\hline $\mathrm{N}$ & 3,579 & & 5,747 & & 5,458 & & & & & & & \\
\hline
\end{tabular}


Table 4: Initial Loan to Value Ratio function

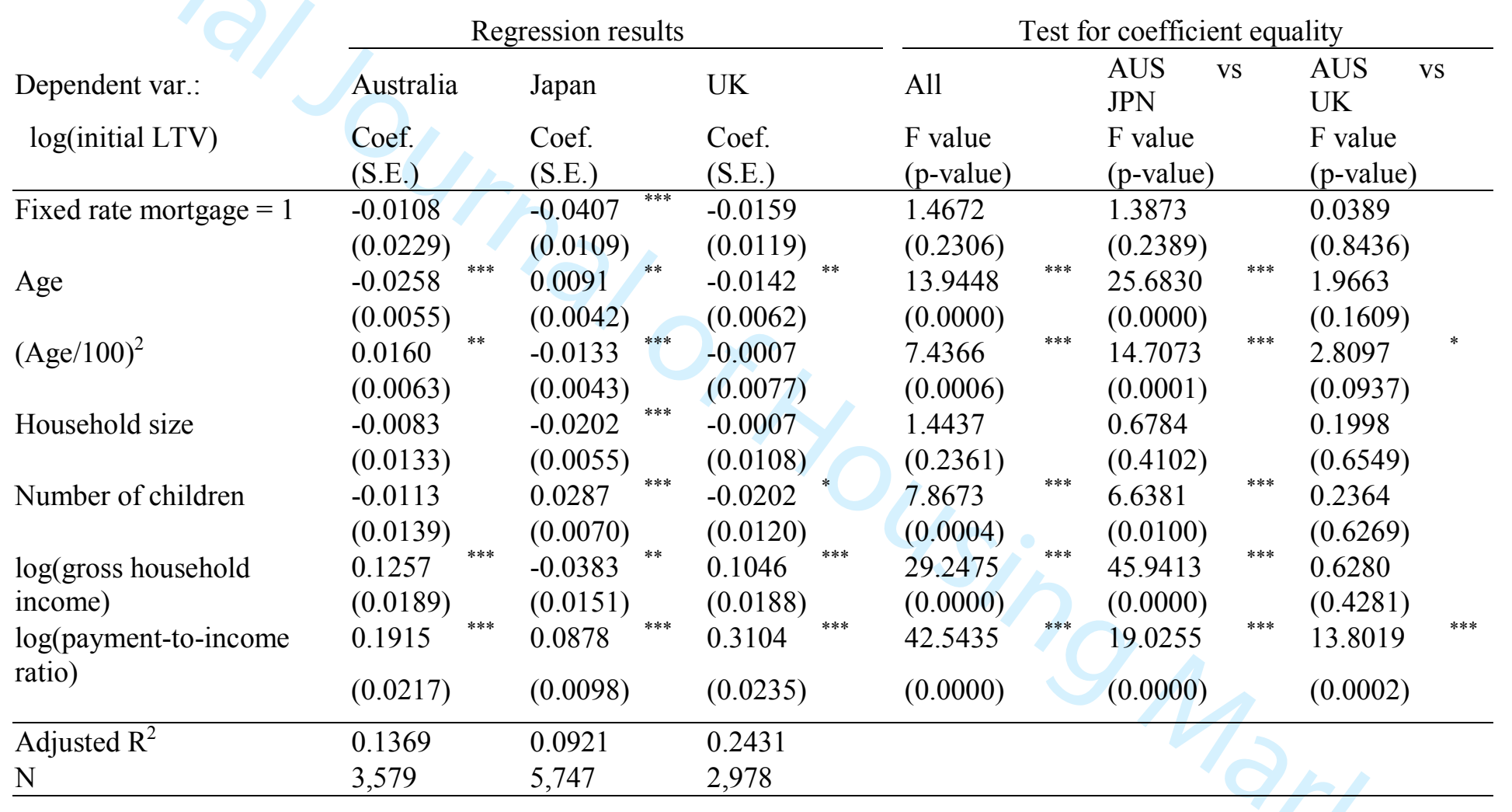


Table 5: Estimates of function incorporating time period as independent variables

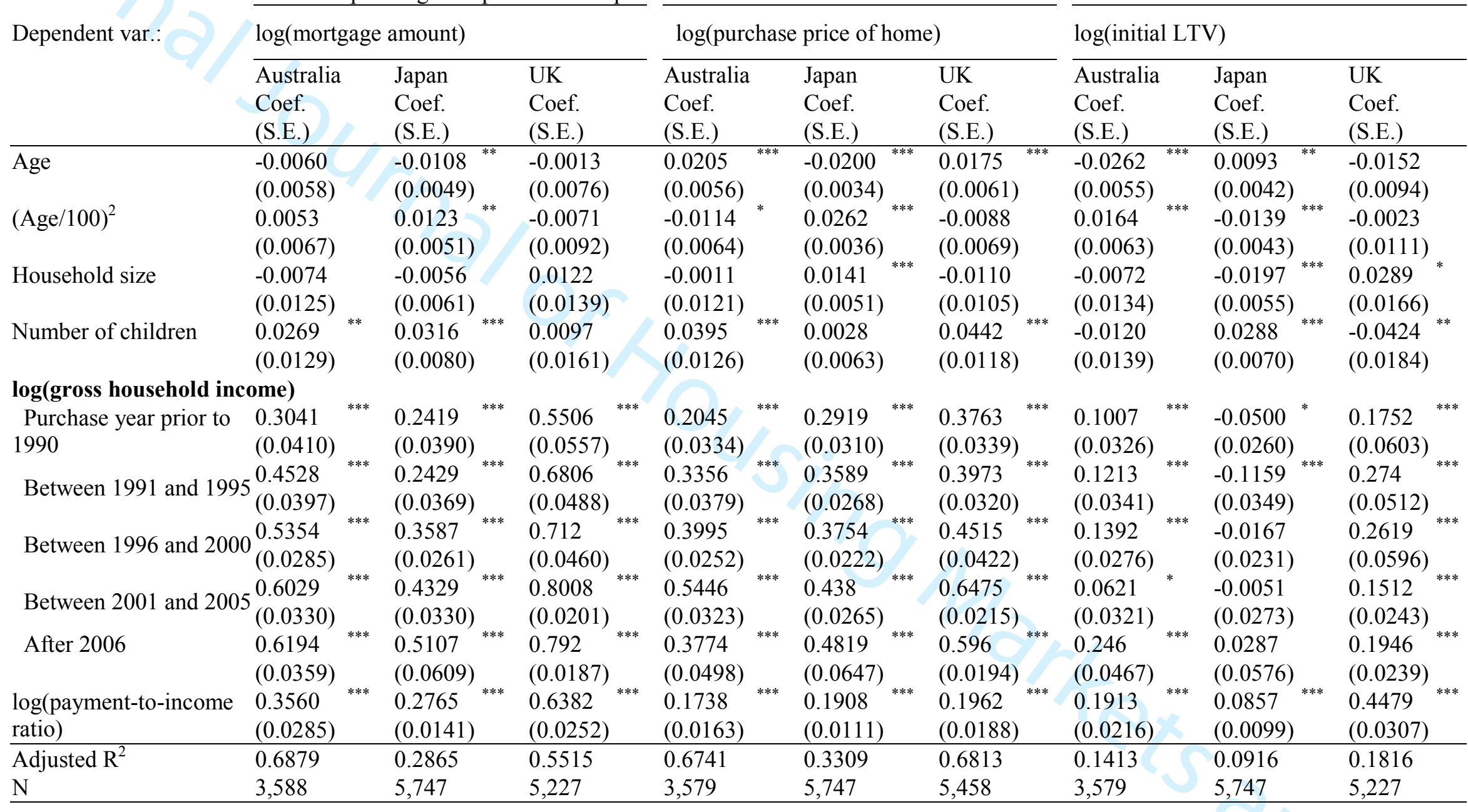

Notes: ${ }^{* * *},{ }^{* *}$, and ${ }^{*}$ indicate that the estimated coefficient is significant at 1, 5 and $10 \%$, respectively. Robust standard errors in parentheses. Fixed effects for urban/rural area, regions, and year of mortgage origination are controlled in all estimation but omitted from the results. 
